\title{
Psikolojik Güçlendirme ve Örgütsel Özdeşleşme Arasında Birey-Örgüt Uyumunun Aracı Rolü
}

\author{
The Mediating Role of Person-Organization Fit between Psychological Empowerment and \\ Organizational Identification
}

\section{Engin Kanbur}

Sivil Hava Ulaştırma İşletmeciliği Bölümü, Kastamonu Üniversitesi, Kastamonu, Türkiye

Özet

Bu çalışmanın amacı, psikolojik güçlendirmenin örgütsel özdeşleşme üzerindeki etkisinin incelenmesinde birey-örgüt uyumunun aracılık etkisinin araştırılmasıdır. Araştırmanın örneklemi, havacılık sektöründe uçakların ve parçalarının bakım, onarım ve revizyon faaliyetlerini yürütmekte olan bir işletmede görev yapan 213 çalışandan oluşmaktadır. Araştırmanın verileri anket tekniği ile toplanmış ve araştırmada Psikolojik Güçlendirme Ölçeği, Örgütsel Özdeşleşme Ölçeği ve BireyÖrgüt Uyumu Ölçeği kullanılmıştır. Araştırmada değişkenler arasındaki ilişkiyi ölçmek amacıyla korelasyon analizi, nedenselliği ölçmek amacıyla doğrusal regresyon analizi ve aracılık etkisini ölçmek amacıyla ise hiyerarşik regresyon analizinden yararlanılmıştır. Araştırmanın bulgularına göre; psikolojik güçlendirme ile örgütsel özdeşleşme ve birey-örgüt uyumu arasında pozitif ve anlamlı bir korelasyonun ve regresyonun olduğu görülmüştür. Psikolojik güçlendirmenin örgütsel özdeşleşme üzerindeki etkisinde birey-örgüt uyumunun kısmı aracılık etkisi olduğu, ancak psikolojik güçlendirmenin alt boyutları açısından herhangi bir aracılık etkisinin olmadığı tespit edilmiştir.

Anahtar Kelimeler: Psikolojik Güçlendirme, Örgütsel Özdeşleşme, Birey-Örgüt Uyumu

\begin{abstract}
The purpose of this study is to investigate the mediating effect of personorganization fit on the examination of the effect of psychological empowerment on organizational identification. Sample of the research consists of 213 employees working in an organization which conducts maintenance, renovation and overhauling activities of aircrafts and their parts in aviation sector. Data of the research were collected by questionnaire method and Psychological Empowerment Instrument Scale, Organizational Identification Scale and Person-Organization Fit Scale were used in the research. In the research, correlation analysis was used to measure relationship between variables, linear regression analysis was used to measure causality and also hierarchical regression analysis was used to measure mediation effect. According to the findings of the research; it can be seen that there is a positive and meaningful correlation and regression between psychological empowerment and organizational identification and person-organization fit. It has been found that person-organization fit partially mediates the effects of psychological empowerment on organizational identification, but there is no mediation effect in the context of sub-dimensions of psychological empowerment. Key Words: Psychological Empowerment, Organizational Identification, PersonOrganization Fit.
\end{abstract}

CONTACT : Engin Kanbur, ekanbur@kastamonu.edu.tr

Geliş Tarihi \& First Received : 24.05.2017

Kabul Tarihi \& Accepted : : 02.06.2017 


\section{Giriş}

Örgütler, acımasız rekabet ortamında rakipleri ile yarışabilmek ve sürdürülebilir rekabeti sağlayabilmek için yeterliliği olan, işine bağlı, proaktif, bilgi ve tecrübe sahibi, yaratıcı ve girişimci gibi niteliklere sahip ve güçlendirilmiş çalışanlara ihtiyaç duymaktadırlar. Çalışanlar ise, bir gruba ait olma, sosyalleşme, kariyer sahibi olma ve ihtiyaçlarını karşılamak, geleceklerini güvence altına almak ve belirsizliği azaltmak için örgütleri ile özdeşleşmektedirler. Örgütler, çalışanlarını güçlendirdikçe ve çalışanlar da bu güçlendirmeyi olumlu olarak algıladıkça örgütleri ile uyum sağlama ve dolayısıyla bağlanma ve özdeşleşme ihtiyaçları daha da önem kazanmaktadır. Örgüt ise, çalışanlarının özdeşleşme düzeyini artırmak istemekte, çünkü yüksek özdeşleşme düzeyinin çalışanların performanslarına olumlu etkisi olduğu belirtilmektedir. Özdeşleşme derecesi ne kadar yüksekse, örgüt de bireyi güçlendirecek ve bu sayede birey-örgüt uyumu sağlanabilecektir. Bu durum hem çalışana bir kimlik kazandıracak ve onların verimliliğini arttıracak hem de örgüt amaçlarına ulaşabilmesini sağlayacaktır. Psikolojik güçlendirme, çalışanların örgüt içindeki rollerine ilişkin hedeflerin gerçekleştirebileceğine olan inançları ve bu hedeflerin gerçekleşmesini engelleyen veya artıran faktörler hakkında farkındalıkları ve bununla ilgili çabalarını içermektedir. Örgütsel özdeşleşme, bireyin örgütü ile ilgili inançları ve değerleri, kendi ile özdeşleştirmesi, bağdaştırması ve özümsemesi şeklinde tanımlanabilir. Motivasyonun temeli olarak görülen örgütsel özdeşleşme, çalışanın örgütüne karşı duyduğu bağlılık ve aidiyet olarak belirtilebilir. Birey-örgüt uyumu ise, birey ile çalıştığı örgüt arasındaki değerlerde, isteklerde, amaçlarda, hedeflerde ve beklentilerde sağlanan uyum olarak tanımlanabilir. Çalışmada, çalışanların psikolojik güçlendirme algılarının örgütsel özdeşleşme düzeyleri üzerindeki etkisinin incelenmesinde birey-örgüt uyumunun aracılık etkisinin araştırılması amaçlanmıştır. Bu amaç doğrultusunda öncelikle ilgili kavramların alan yazındaki taramaları yapılmıştır. Daha sonra edinilen bilgiler ışı̆̆ında araştırmanın yöntemi belirlenerek değişkenler arasındaki uygulanacak analizler gerçekleştirilmiş, edinilen bulgular kapsamında değerlendirmeler yapılmış ve gerekli önerilerde bulunulmuştur.

\section{Yazın Taramasi}

\subsection{Psikolojik Güçlendirme}

Örgütsel anlamda güç, başkalarını etkileyebilme ve kendi istediği yönde davranışa yönlendirebilme yeteneğidir. Dolayısıyla güç, bireyler arasındaki ilişkileri ifade etmektedir (Koçel, 2001: 449). Bireyin güç sahibi olup olmadığı, ancak diğer bireylerle ilişki kurduğu zaman ortaya çıkabilir. Örneğin; bir çalışan, kıt bir kaynağ1 elinde bulunduran diğer bir çalışana bağımlıysa, o çalışan diğer çalışana göre güçsüzdür denilebilir (Can vd., 2015: 245). Güçlendirme, bilgi, tecrübe ve gücün çalışanlar ile paylaşılması, karar verme gücünün çalışanlar arasında yeniden dağıtılması, çalışanlara işlerin nasıl daha etkin ve verimli yapılabileceği hususunda yetki ve sorumluluk verilmesi olarak tanımlanabilir (Pelit ve Öztürk, 2011: 3). Güçlendirme, üst yönetim tarafından bilginin, enformasyonun ve gücün daha alt kademedeki çalışanlar ile paylaşılması, onlara yetki ve sorumluluk verilmesi, 
çalışanların ise yaptığı işe sahip çıkması, sorumluluk alması olarak tanımlanabilir (Kesen, 2015: 6532; Hales ve Klidas, 1998: 89). Güçlendirme kavramını ilk olarak dile getiren Conger ve Kanungo'ya (1988) göre güçlendirme, içsel bir motivasyon aracıdır ve çalışanların yaptığ işe ve işin gerektirdiği rollere ilişkin algılamalardır. (Toplu ve Akça, 2013: 225). Honold'a göre (1997) güçlendirme kavramı enerji verme, teşvik etme, yönlendirme, isteklendirme gibi motive edici bir yönünün bulunduğuna dikkat çekmektedir (Hemedoğlu vd., 2012: 89).

Psikolojik güçlendirme, var olan gücün çalışanlar ile paylaşılması gibi yönetimsel uygulamalara odaklanmak yerine, çalışanların işlerini nasıl daha iyi yapacakları konusuna odaklanan psikolojik bir süreçtir. Bu süreç, çalışanların örgüt içinde üstlendikleri rolleri konusunda sahip oldukları kişisel inançlarını içermektedir (Altındiş ve Özutku, 2011: 166; Spreizer, 2007: 57). Psikolojik güçlendirme, çalışanların örgüt içindeki rollerine ilişkin hedeflerin gerçekleştirebileceğine olan inançları ve bu hedeflerin gerçekleşmesini engelleyen veya artıran faktörler hakkında farkındalıkları ve bununla ilgili çabalarını içermektedir (Zimmerman, 1995: 582). Aynı zamanda psikolojik güçlendirme, motive etme, çalışanların iş yapabilme gücünü arttırma, değerlerini ve özerklik duygularını canlandırma, harekete geçirme ve kendilerini psikolojik olarak güvende hissetme olarak da yazında sıkça kullanılmaktadır (Çalışkan, 2011: 79). Psikolojik güçlendirmenin daha yüksek seviyelerde gerçekleşmesi beraberinde, çalışanlar daha yüksek bir içsel motivasyon sağlayabilir. Bu durumun verilen görevler üzerinde yoğun dikkat, daha fazla çaba, güçlüklere karşı direnç ve gelişmiş görev stratejileri ile sonuçlanması beklenmektedir (Hall, 2008: 146).

Thomas ve Velthouse (1990) tıpkı Conger ve Kanungo gibi güçlendirmeyi, çalışanın işteki rolüne uyumunu ve bütünlüğünü yansıtan anlam, yetkinlik, özerklik (otonomi) ve etki gibi dört algıdan oluşan motivasyonel bir yap1 olarak tanımlamaktadırlar. Aynı şekilde Spreitzer da (1995) güçlendirmeyi bu dört boyutta incelemekte ve çalışanın işteki rolüne karşı daha aktif bir yönelimini yansıttığını savunmaktadır (Spreitzer vd., 1997: 681; Singh vd., 2015: 56; Jha, 2014: 21; Hu ve Leung, 2003: 368; Laschinger vd., 2004: 529; Taştan, 2012: 229; Kanbur, 2016: 2). Anlamlllık (Meaning), çalışanda mevcut olan değer, inanç, tutum, tecrübe ve davranışları ile yaptığı iş ve işin gerekleri ve amaçları arasındaki uyum olarak tanımlanabilir (Spreitzer, 1995: 1443; Yürür ve Demir, 2011: 314). Yeterlilik (Competence), çalışanların iş ve eylemleri daha iyi organize edebilmeleri konusunda kendilerine ve sahip oldukları yeteneklerine karşı duydukları güven düzeyi ile ilgilidir (Bandura, 1995: 26; Sürgevil vd., 2013: 5374; Kanbur vd., 2016: 20). Özerklik (Self-determination), çalışanın üst yönetimden bağımsız olarak işlerin nasıl yapılacağı, ne tür çabaların harcanacağı ve hangi yöntemlerin kullanılacağı konusunda kendi kendine karar alabilme özgürlüğünü ifade etmektedir (Spreitzer vd., 1996: 512; Karakaş ve Serçek, 2014: 92). Etki (Impact), çalışanın kendi çalışma yerindeki stratejik, yönetsel ya da işlevsel faaliyetleri ve sonuçları etkileyebileceği inancıdır (Yücel ve Demirel, 2012: 22; Whitaker ve Westerman, 2014: 270). 


\section{2. Örgütsel Özdeşleşme}

Özdeşleşme, Sosyal Kimlik Kuramı kapsamında değerlendirilebilen ve bu kuram üzerine odaklanmış önemli kavramlardan biridir (Knippenberg ve Schie, 2000: 138). Özdeşleşme, örgütün amaç ve değerlerine, bunları gerçekleştirecek olan bireyin kendi rolüne ve örgütüne karşı yanlı ve duyuşsal bir bağl1lıktır (Polat ve Meydan, 2011:156). Örgütsel özdeşleşme, sosyal özdeşleşmenin ve bağlılığın örgüt içinde ele alınmasıyla ortaya çıkmış, önem kazanmış bir kavramdır. Dolasıyla örgütsel özdeşleşme kavramını açıklamadan önce sosyal özdeşleşmeyi kavramak konunun bütünlügü ve anlaşılması açısından fayda sağlayabilir (Riketta, 2005: 360; Dick, 2001: 267). Sosyal özdeşleşme, bir ekibe, gruba, topluluğa bağlı olma, ait olma algısı olarak belirtilebilir. Birey kendini bu topluluğun gerçek bir üyesi olarak algılar. Böylece bireyin kendisi hakkındaki "ben kimim, ne yapıyorum vb." sorularına kısmen de olsa cevap verir (Karabey ve İşcan, 2007: 232). Özdeşleşmeye örgütsel açıdan bakıldığında; kişinin belirli bir örgütün üyesi olarak kendisini tanımladı̆̆ı sosyal kimlik biçimidir (Mael ve Ashforth, 1992: 105).

Örgütsel özdeşleşme, çalışanın sahip olduğu amaç ve hedeflerini çalıştığ örgütün amaç ve hedefleri ile uyumlaştırması, bağdaştırması ve bunun sonucunda çalışanın kendini örgütün veya grubun bir parçası, bir üyesi gibi hissetmesi veya algılamasıdır (Sökmen vd., 2015: 128). Örgütsel özdeşleşme, bireyin örgütü ile ilgili inançları, değerleri kendi ile özdeşleştirmesi, bağdaştırması ve özümsemesi şeklinde tanımlanabilir (Carmeli vd., 2007: 974). Motivasyonun temeli olarak görülen örgütsel özdeşleşme, çalışanın kendinden bir parça ve değer olarak gördüğü ve algıladığı örgütüne karşı duyduğu bağlılık ve aidiyet olarak tanımlanabilir (Tokgöz ve Seymen, 2013: 63). Örgütsel özdeşleşme, çalışanları örgütün kural ve talimatlarına uygun davranış kalıpları sergilemeyi, örgütün amaç ve değerlerini kendi amaç ve değerleri gibi görmeyi sağlar (Çetinkaya ve Çimenci, 2014: 240). Örgütsel özdeşleşme, örgütte aidiyet duygusunun ve kontrolünün sağlanmasına yardımcı olmaktadır. Örgütsel özdeşleşmenin birçok olumlu etkisi olduğu gibi bazı olumsuz etkileri de olabilmektedir. Örneğin; bireyin örgütü ile aşırı özdeşleşmesi bireyi işi ile ilgili tamamen tüketebilir ve örgüte olan bağlılığını kaybettirebilir (Kreiner ve Ashforth, 2004: 2).

\subsection{Birey-Örgüt Uyumu}

Bireyler kendi sahip oldukları özelliklere (psikolojik, sosyolojik, kültürel vb.) sahip bireylerle etkileşim, iletişim içine girmeye diğer bireylere nazaran daha fazla istekli olabilirler. Bu durumun sebebi olarak, etkileşimin bireylerin kendi değerlerini, tutumlarını, inançlarını ve davranışlarını sınamalarına imkan vermesidir (Akbaş, 2011: 57). Birey-örgüt uyumu çalışmalarının temelini Murray (İhtiyaç Baskı Modeli) ve Lewin'in (Alan Teorisi) teorileri oluşturmaktadır (Polatçı vd., 2014: 2). Bu teorilere göre birey-örgüt uyumu; insan davranışlarını, birey ve etkileşimde bulunduğu çevresinin bir sonucu olarak tanımlamasına dayanmaktadır. Örgütsel açıdan bakıldığında birey-örgüt uyumu, bireylerin iş ile ilgili tutum ve davranışlarını etkileyen bir süreçken, genel anlamda, bireyin sahip olduğu değer, norm, inanç, amaç 
ve beklentilerinin çalıştı̆̆ı örgüt ve/veya iş arasındaki uyum olarak tanımlanabilir (Chatman, 1989: 339; Polatçı ve Cindiloğlu, 2013: 301).

Birey-örgüt uyumu, birey ile çalıştığı örgüt arasındaki değerlerde, isteklerde, amaçlarda, hedeflerde, beklentilerde sağlanan uyum (Autry ve Daugherty, 2003), örgütün sahip olduğu kültürel özelliklerle bireyin sahip olduğu değerleri ve kişilik özellikleri arasındaki uygunluk veya örtüşme, örgütün değer yargıları ile bireyin değer yargıları arasındaki uyum, ahenk olarak tanımlanabilir (Sezgin, 2006: 559). Birey-örgüt uyumunun örgütlerde sağlıklı olarak ölçülebilmesi, ortaya konulabilmesi için Kristof (1996) tarafından önerilen üç ölçüm yöntemi vardır. Birincisi, bireye kendisi ile çalıştı̆̆ı örgütün ne düzeyde bir uyumunun sorulduğu sübjektif uyum ölçüm yöntemidir. İkincisi, bireyin önce kendi özelliklerini tanımladığı sonra ise çalıştığ1 örgütün özelliklerini tanımladığ1 ve böylece uyumun karşılaştırıldığ algılanan uyum ölçüm yöntemidir. Son olarak ise, bireye kendi özelliklerinin ve diğer örgüt çalışanlarına da örgütün özelliklerinin sorulduğu ve böylece karşılaştırmanın yapıldı̆̆1 objektif uyum ölçüm yöntemidir (Pekdemir vd., 2013: 86; Hoffman ve Woehr, 2006: 391). Birey-örgüt uyumu ile örgütsel bağlllık (Meyer vd., 2010; Verguer vd., 2003), kariyer başarısı (Bretz ve Judge, 1994), iş tatmini (Silverthorne, 2004; Cable ve Judge, 1994), performans ve motivasyon (Sekiguchi, 2004), proaktif davranış (Kim vd., 2005), örgütsel vatandaşlık davranışı (Polatçı ve Cindiloğlu, 2013; Zhao, 2009) arasında pozitif ve anlamlı, işten ayrılma niyeti (Liu vd., 2010; Horffman ve Woehr, 2006) ve iş stresi (Bulut ve Torun, 2007) arasında ise negatif ve anlamlı bir ilişki olduğu söylenebilir.

\subsection{Psikolojik Güçlendirme, Örgütsel Özdeşleşme ve Birey-Örgüt Uyumu İlişkisi}

Psikolojik güçlendirme ve örgütsel özdeşleşme birtakım önemli örgütsel çıktıların çok iyi yordayıcıları olarak dikkat çekmektedir. Çalışanların güçlenme algılarının artmasının örgütüyle özdeşleşmesini artırabileceği bazı teoriler (Karşılıklılık Teorisi, Örgütsel Destek Kuramı, Sosyal Mübadele Kuramı vb.) kapsamında söylenebilir. Çalışanın gücü daha fazla artarsa, örgütüne ilişkin memnuniyet düzeyi artarsa, örgüte daha belirgin bir şekilde karşllı vereceği ve örgütü ile özdeşleşeceği söylenebilir (Prati ve Zani, 2013: 853).

Hipotez 1: Çalışanların psikolojik güçlendirme algıları örgütsel özdeşleşmeyi pozitif yönde etkiler.

Hipotez 1a: Psikolojik güçlendirmenin alt boyutu olan "anlamlılık" örgütsel özdeşleşmeyi pozitif yönde etkiler.

Hipotez 1b: Psikolojik güçlendirmenin alt boyutu olan "yeterlilik" örgütsel özdeşleşmeyi pozitif yönde etkiler.

Hipotez 1c: Psikolojik güçlendirmenin alt boyutu olan "özerklik" örgütsel özdeşleşmeyi pozitif yönde etkiler.

Hipotez 1d: Psikolojik güçlendirmenin alt boyutu olan "etki" örgütsel özdeşleşmeyi pozitif yönde etkiler. 
Psikolojik güçlendirme ile çalışanların örgüt içindeki rollerine ilişkin hedeflerin gerçekleştirebileceğine olan inançları, bilgileri ve tecrübeleri ne kadar artarsa çalışanlar da örgütleri ile daha fazla bütünleşebilir, uyum sağlayabilir ve aynı doğrultuda amaç birliği oluşturabilir.

Hipotez 2: Çalışanların psikolojik güçlendirme algıları birey-örgüt uyumunu pozitif yönde etkiler.

March ve Simon'a (1958) göre, çalışanın örgütü prestijli, itibarlı olarak algılaması, örgütsel amaçları benimsemesi ve örgüt ile etkileşiminin sık olması, çalışanlar arasındaki rekabetin düşük seviyede olması ve örgütün çalışanlarının ihtiyaçlarını tatmin etmesi durumunda örgütle özdeşleşme sağlanmaktadır (Tak ve Çifçioğlu, 2009:101).

Hipotez 3: Birey-örgüt uyumunu örgütsel özdeşleşmeyi pozitif yönde etkiler.

Çalışanların psikolojik güçlendirme algılarının artırılması onların örgütlerine karşı duydukları bağlılı̆̆ı artırabilir, örgütleri ile daha fazla özdeşleşebilirler. Örgüt içerisinde birey-örgüt uyumunun tam olarak sağlanması, çalışanların kendilerini örgütün ayrılmaz bir parçası olarak görebilmelerine ve özdeşleşme düzeylerinin artmasına neden olabilir.

Hipotez 4: Çalışanların psikolojik güçlendirme algıları örgütsel özdeşleşme üzerindeki etkisinde birey-örgüt uyumunun aracılık rolü vardır.

Hipotez 4a: Psikolojik güçlendirmenin alt boyutlarından olan "anlamlılık" boyutunun örgütsel özdeşleşme üzerindeki etkisinde birey-örgüt uyumunun aracılık rolü vardır.

Hipotez 4b: Psikolojik güçlendirmenin alt boyutlarından olan "yeterlilik" boyutunun örgütsel özdeşleşme üzerindeki etkisinde birey-örgüt uyumunun aracılık rolü vardır.

Hipotez 4c: Psikolojik güçlendirmenin alt boyutlarından olan "özerklik" boyutunun örgütsel özdeşleşme üzerindeki etkisinde birey-örgüt uyumunun aracılık rolü vardır.

Hipotez 4a: Psikolojik güçlendirmenin alt boyutlarından olan "etki" boyutunun örgütsel özdeşleşme üzerindeki etkisinde birey-örgüt uyumunun aracılık rolü vardır.

\section{Metodoloji}

Bu bölümde; araştırmanın amacı, önemi, kapsamı, evren ve örneklemi, kısıtları, veri toplama yöntemi, kullanılan ölçekler, faktör ve güvenilirlik analizlerine yer verilmektedir.

\subsection{Araştırmanın Amacı, Önemi ve Kapsamı}

Araştırmanın amacl, psikolojik güçlendirmenin örgütsel özdeşleşme üzerindeki etkisinin incelenmesinde birey-örgüt uyumunun aracılık etkisinin araştırılmasıdır. Örgütler, belirledikleri amaçlara ulaşabilmek, rakipleri ile rekabet edebilmek ve sürdürülebilirliği sağlayabilmek için bilgili, tecrübeli, proaktif, yaratıcı ve yenilikçi 
çalışanlara ihtiyaç duymaktadır. Bu tür özellikler çalışanlarda kendiliğinden oluşmakta, örgütlerin bu gibi konularda çalışanlarının eksikliklerini anlayıp, onları güçlendirmeleri gerekmektedir. Çalışanlar ise, bağlılık ihtiyaçlarını giderebilecekleri, kendilerini güvende hissedecekleri, gelecek kaygısının ve belirsizliklerin olmadığı bir ortam aramaktadır. Sosyal kimlik kuramı gereği çalışanlar, örgütün üyesi olmak ve kendini ait hissetmek yani örgütü ile özdeşleşmek istemektedirler. Çalışanın örgütü ile özdeşleşmesi, örgütün de amaçlarına ulaşabilmesi birey-örgüt uyumunun tam olarak sağlanması ile mümkün olabilmektedir. Örgüt çalışanlarını eksik oldukları konularda güçlendirecek, güçlenen çalışan örgütü ile özdeşleşecek ve sonuç olarak sosyal mübadele kuramı, karşılıklılık kuramı ve örgütsel destek kuramı çerçevesinde "kazan-kazan" mantığı gerçekleşmiş olacaktır.

\subsection{Araştırmanın Evreni, Örneklemi ve Kısıtları}

Araştırma evrenini, havacılık sektöründe uçak ve parçalarının bakım, onarım ve revizyon faaliyetlerini sürdüren bir işletmede görev yapan 440 çalışan oluşturmaktadır. Araştırmada kolayda örnekleme yöntemi kullanılmıştır. Toplam 440 çalışandan oluşan araştırma evreni, $\alpha=.05$ güven düzeyi ve \pm .05 hata seviyesinde en az 206 çalışandan oluşan bir örneklem grubu ile temsil edilebilmektedir (Altunışık vd., 2004: 125). Araştırma sürecinde 250 anket formu işletmeye gönderilmiş ve $\% 88,4$ yanıtlanma oranıla 221 anketin geri dönüşümü sağlanmıştır. Cevaplanan 221 anketin 5'iı tamamlanmamış ve 3'ü güvenilmeyen yanitlar yüzünden araştırmaya dahil edilmemiştir. Böylece 213 kullanılabilir anket araştırma evrenini temsil edecek niteliktedir. Araştırmanın kısıtları; araştırmanın havacılık sektöründe uçak ve parçalarının bakım, onarım ve revizyon işlemlerini sürdüren bir işletmesindeki çalışanlarla yapılması, veri toplama aracı olarak anket yönteminden yararlanılması ve kullanılan ölçeklerle sınırlandırılması olarak değerlendirilebilir.

\subsection{Araştırmanın Veri Toplama Yöntemi ve Ölçekleri}

Araştırmada verilerinin güvenilir bir şekilde toplanabilmesi ve araştırma hipotezlerinin test edilebilmesi amacıyla anket yönteminden yararlanılmıştır. Araştırmada çalışanların psikolojik güçlendirme algılarını belirlemek amacıyla, Spreitzer (1995 - $\alpha=.72$ ) tarafından geliştirilen Çekmecelioğlu ve Eren (2007), Çöl (2008), Tolay vd. (2012 - $\alpha=.86)$ tarafından çalışmalarında yararlandıkları geçerliliği ve güvenilirliği kanıtlanmış "Psikolojik Güçlendirme Ölçeği" (Psychological Empowerment Instrument-PEI) kullanılmıştır. Ölçek dört boyuttan ve her bir boyutta üçer madde olmak üzere toplam 12 maddeden oluşmaktadır. Ölçekte, "Yapmakta olduğum iş benim için çok önemlidir", "İşimi yapmak için yeteneklerime güveniyorum", "İşimi nasıl yapacağıma kendim karar verebilirim" ve "Çalıştığım bölümde olanlar üzerinde büyük bir kontrole sahibim " gibi sorular yer almaktadır. Puanlama, 5'li likert ölçeğine göre yapılmıştır (1=kesinlikle katılmıyorum; $5=$ kesinlikle katılıyorum).

Örgütsel özdeşleşmeyi ölçmek amacıyla, Mael ve Ashforth (1992 - $\alpha=.87$ ) tarafından geliştirilen ve Tak ve Aydemir (2004) tarafından Türkçe'ye uyarlanan, Tüzün (2006 - $\alpha=.78)$, Turunç ve Çelik (2010 - $\alpha=.84)$ tarafından çalışmalarında 
yararlandıkları geçerliliği ve güvenilirliği kanıtlanmış "Örgütsel Özdeşleşme Ölçeği” (Organizational Identification Scale-OIS) kullanılmıştır. Ölçek tek boyuttan ve 6 maddeden oluşmaktadır. Ölçekte, "Biri işletmemi eleştirdiğinde, kendimi hakarete uğramış gibi hissederim." ve "İşletmemin başarısı benim başarımdır" gibi sorular yer almaktadır.

Örgütlerde birey-örgüt uyumunu ölçmek için Netemeyer, Boles, McKee ve McMurrian (1997 - $\alpha=.88)$ tarafından geliştirilen, Valentine vd. (2002 - $\alpha=.91)$ Akbaş (2011 - $\alpha=.94)$, Pekdemir vd. (2013 - $\alpha=.89)$ tarafından çalışmalarında yararlandıkları geçerliliği ve güvenilirliği kanıtlanmış "Birey-Örgüt Uyumu Ölçeği" (PersonOrganization Fit Scale- POFS) kullanılmıştır. Ölçek, tek boyut ve 4 maddeden oluşmaktadır. Ölçekte, “Bu işletmenin değerleri ile kişisel değerlerimin uyumlu olduğunu düşünüyorum" ve "Bu işletmenin dürüstlük konusundaki değerleri ile benim değerlerim aynıdır" gibi sorular yer almaktadır. Ölçeklerin puanlamaları, 5’li likert ölçeğine göre yapılmıştır.

\subsection{Faktör ve Güvenilirlik Analizleri}

Araştırmada kullanılan psikolojik güçlendirme ölçeği, örgütsel özdeşleşme ölçeği ve birey-örgüt uyumu ölçeklerinin iç tutarlılık analizi Cronbach Alfa ile incelenmiştir. Ölçeklerin Cronbach Alfa değerleri güvenilirlik için kabul edilebilirlik sınırı olan \%70'in üzerindedir. Araştırmada kullanılan ölçeklerin yapı geçerliliğini ölçmek amacıyla faktör analizinden yararlanılmıştır. Analiz bulguları Tablo 1'de gösterilmektedir. Ayrıca, verilerin çarpıklık (Skewness) ve basıklık (Kurtosis) değerlerine bakılmış ve analizlere uygun olduğu yani normal dağılım gösterdiği söylenebilir.

Tablo 1. Faktör ve Güvenilirlik Analizi ile Bulguları

\begin{tabular}{|c|c|c|c|c|c|}
\hline 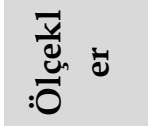 & Faktörler & $\begin{array}{c}\text { Madde } \\
\text { Sayısı }\end{array}$ & $\begin{array}{l}\text { Fak. Yük. } \\
\text { Aralı̆ğ }\end{array}$ & $\begin{array}{l}\text { Açlklanan } \\
\text { Varyans (\%) }\end{array}$ & $\begin{array}{l}\text { Cronbach } \\
\text { Alpha }(\alpha)\end{array}$ \\
\hline \multirow{6}{*}{ 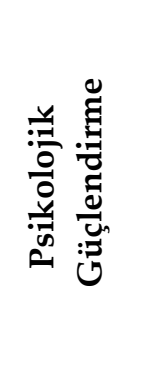 } & Psikolojik Güçlendirme & 12 & 606 - 845 & 66,265 & $.81,6$ \\
\hline & - Anlamllik-Yeterlilik & 6 & ,606- , 816 & 27,201 & $.83,3$ \\
\hline & - Özerklik & 3 & ,809- - 831 & 19,548 & $.78,3$ \\
\hline & - Etki & 3 & ,832-, 845 & 19,516 & $.87,0$ \\
\hline & Kaiser-Meyer-Olkin örnekl & eterliliği & eri: ,795 & & \\
\hline & Barlett küresellik testi: ki-k & $=1105,870$ & $f=66 ; p=, 000$ & & \\
\hline \multirow{2}{*}{ 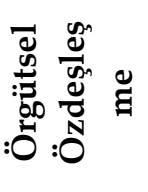 } & Örgütsel Özdeşleşme & 6 & ,583 - , 844 & 56,224 & $.83,7$ \\
\hline & Kaiser-Meyer-Olkin örnekl & eterliliğic & eri:, 827 & & \\
\hline \multirow{3}{*}{ 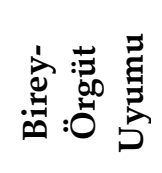 } & & & & & \\
\hline & Birey-Örgüt Uyumu & 4 & 618 - 844 & 58,200 & $.74,6$ \\
\hline & \multicolumn{5}{|c|}{$\begin{array}{l}\text { Kaiser-Meyer-Olkin örneklem yeterliliği değeri: }, 726 \\
\text { Barlett küresellik testi: } \text { ki-kare=221,834; } \mathrm{df}=6 ; \mathrm{p}=, 000\end{array}$} \\
\hline
\end{tabular}


Psikolojik güçlendirme değişkeninin dört boyutu yapılan faktör analizi sonucunda anlamlılık ve yeterlilik boyutlarının tek faktörde (Çöl, 2008) toplanması ile ilgili değişken üç boyut olarak değerlendirilmiştir. Bu sonuçlardan sonra oluşturulan araştırma modeli Şekil 1'de sunulmuştur.

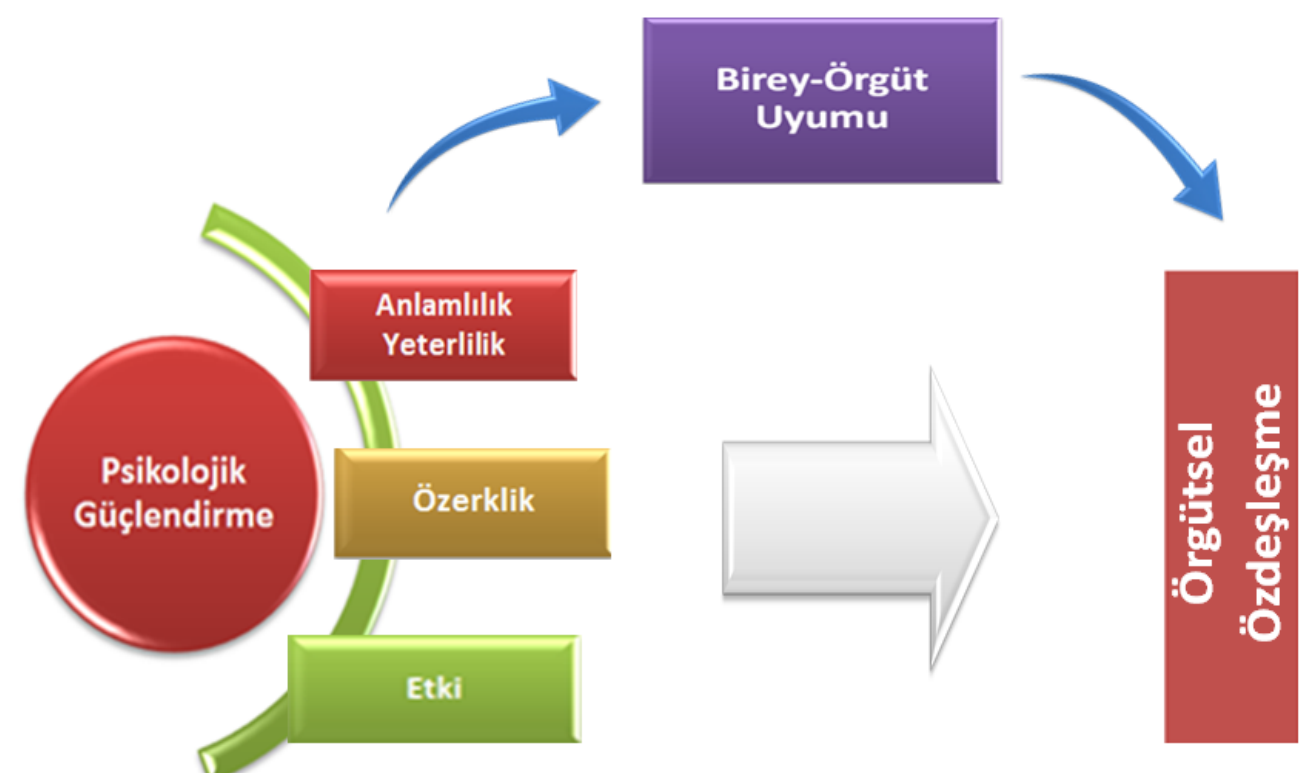

Şekil 1. Araştırma Modeli

\section{Bulgular}

\subsection{Korelasyon Analizi ve Bulguları}

Çalışmada değişkenler arasındaki şiddeti ve ilişkiyi ölçmek amacıyla korelasyon analizinden yararlanılmıştır (Tablo 2).

Tablo 2. Değişkenler Arasındaki Korelasyon Analizi ve Bulguları

\begin{tabular}{|c|c|c|c|c|c|c|c|}
\hline \multicolumn{2}{|c|}{ Değişkenler } & \multirow{2}{*}{$\frac{1}{1}$} & \multirow[t]{2}{*}{2} & \multirow[t]{2}{*}{3} & \multirow[t]{2}{*}{4} & \multirow[t]{2}{*}{5} & \multirow[t]{2}{*}{6} \\
\hline 1 & Psikolojik Güçlendirme & & & & & & \\
\hline 2 & Anlamlilık-Yeterlilik & ,700* & 1 & & & & \\
\hline 3 & Özerklik &, $720^{*}$ & $169^{* *}$ & 1 & & & \\
\hline 4 & Etki &, $727^{*}$ & $176^{* *}$ & $483^{*}$ & 1 & & \\
\hline 5 & Örgütsel Özdeşleşme & $379^{*}$ &, $503^{*}$ & ,080 & $158^{* *}$ & 1 & \\
\hline 6 & Birey-Örgüt Uyumu &, $356^{*}$ & $494^{*}$ & $148^{* *}$ &, 047 & $285^{*}$ & 1 \\
\hline
\end{tabular}

${ }^{*} \mathrm{p}<0.01 ;{ }^{* *} \mathrm{p}<0.05$ düzeyinde anlamlıdır 
Tablo 2'de yer alan, psikolojik güçlendirme, örgütsel özdeşleşme ve birey-örgüt uyumu arasındaki korelasyon analizine ilişkin bulgular incelendiğinde; psikolojik güçlendirme ile örgütsel özdeşleşme $(r=, 379 ; p=, 000)$ ve birey-örgüt uyumu $(r=, 356$; $\mathrm{p}<, 01)$ arasında pozitif yönde ve anlamlı bir ilişkinin olduğu görülmektedir. Diğer yandan; psikolojik güçlendirmenin alt boyutlarından "anlamlılık-yeterlilik" boyutunun örgütsel özdeşleşme $(r=, 503 ; \mathrm{p}<, 01)$ ve birey-örgüt uyumu $(r=, 494 ; \mathrm{p}<, 01)$ ile pozitif ve anlamlı, "özerklik" boyutunun birey-örgüt uyumu $(r=, 148$; $p<, 05)$ ile pozitif ve anlamlı bir ilişkisinin olduğu, ancak örgütsel özdeşleşme ile herhangi bir ilişkisinin olmadığı söylenebilir. "Etki" boyutunun ise örgütsel özdeşleşme ( $r=, 154$; $\mathrm{p}<, 05)$ ile pozitif ve anlamlı bir ilişkisinin olduğu, ancak birey-örgüt uyumu ile herhangi bir ilişkisinin olmadığ 1 görülmektedir.

\subsection{Doğrusal Regresyon ve Bulguları}

Çalışmada değişkenler arasındaki nedenselliği ölçmek amacıyla doğrusal regresyon analizinden yararlanılmıştır (Tablo 3, 4, 5). Ayrıca, Durbin-Watson (DW) istatistiği değeri ile atık değerler arasında otokorelasyon olup olmadığını kontrol edilmiştir.

Tablo 3. Psikolojik Güçlendirmenin Örgütsel Özdeşleşme ve Birey-Örgüt Uyumu Üzerindeki Etkisini İncelemeye Yönelik Doğrusal Regresyon Analizi ve Bulguları

\begin{tabular}{lccccccc}
\hline \hline \multicolumn{2}{l}{ Bağımsız Değişken: Psikolojik Güçlendirme } & & & & \\
Bağımlı değişkenler & $\mathbf{R}^{2}$ & $\mathbf{F}$ & $\boldsymbol{\beta}$ & $\mathbf{t}$ & $\mathbf{p}$ & $\mathbf{D W}$ \\
\hline \hline Örgütsel Özdeşleşme & 14,4 & 35,449 &, 379 & 5,954 &, $000^{*}$ & 1,908 \\
\hline Birey-Örgüt Uyumu & 12,7 & 30,598 &, 356 & 5,532 &, $000^{*}$ & 1,882 \\
\hline \hline
\end{tabular}

${ }^{*} \mathrm{p}<0.01$ düzeyinde anlamlıdır.

Tablo 3'de yer alan doğrusal regresyon bulguları incelendiğinde; örgütsel özdeşleşme değişkeninin \%14,4'ünün $\left(\mathrm{R}^{2}=, 144\right)$ ve birey-örgüt uyumu değişkeninin $\% 12,7$ 'sinin $\left(\mathrm{R}^{2}=, 127\right)$ psikolojik güçlendirme değişkeni tarafından açıklandığ görülmektedir. Durbin-Watson istatistiği değerinin 1,5 - 2 değerleri arasında olduğu ve otokorelasyon olmadığı söylenebilir. Tüm bu analiz ve bulgular işı̆̆ında, çalışanların psikolojik güçlendirme algılarının örgütsel özdeşleşmeyi anlamlı ve pozitif yönde $(\beta=, 379, p<, 001)$ etkilediği görülmektedir. Aynı şekilde, çalışanların psikolojik güçlendirme algılarının birey-örgüt uyumunu anlamlı ve pozitif yönde $(\beta=, 356, \quad p<, 001)$ etkilediği söylenebilir. Böylece $\left(\mathrm{H}_{1}\right)$ ve $\left(\mathrm{H}_{2}\right)$ hipotezleri desteklenmektedir.

Tablo 4'de yer alan doğrusal regresyon bulguları incelendiğinde; örgütsel özdeşleşme değişkeninin \%25,3'ünün $\left(\mathrm{R}^{2}=, 253\right)$ ve birey-örgüt uyumu değişkeninin \%24,4'ünün $\left(\mathrm{R}^{2}=, 244\right)$ psikolojik güçlendirme değişkeninin "anlamlılık-yeterlilik" boyutu tarafından açıklandığı görülmektedir. Birey-örgüt uyumu değişkeninin 
\%2,2'sinin ( $\left.\mathrm{R}^{2}=, 022\right)$ psikolojik güçlendirme değişkeninin “özerklik" boyutu tarafından açıklandığı görülmekte olup, örgütsel özdeşleşme değişkeni ile herhangi bir nedenselliğe rastlanmamıştır. Örgütsel özdeşleşme değişkeninin \%2,5'inin $\left(\mathrm{R}^{2}=, 025\right)$ psikolojik güçlendirme değişkeninin "etki" boyutu tarafından açıklandığ görülmekte olup, birey-örgüt değişkeni ile herhangi bir nedenselliğe rastlanmamıştır. Tüm bu analiz ve bulgular 1şığında, $\mathrm{H}_{1 \mathrm{a}-1 \mathrm{~b}}(\beta=, 503, \mathrm{p}<, 001), \mathrm{H}_{2 \mathrm{a}-2 \mathrm{~b}}(\beta=, 224, \mathrm{p}<, 001), \mathrm{H}_{1 \mathrm{~d}}$ $(\beta=, 159, \mathrm{p}<, 05), \mathrm{H}_{2 c}(\beta=, 148, \mathrm{p}<, 05)$ hipotezleri desteklenmiş, diğer hipotezler $\left(\mathrm{H}_{1 c}\right.$ ve $\mathrm{H}_{2 \mathrm{~d}}$ ) ise reddedilmiştir. Ayrıca, Durbin-Watson istatistiği değerinin 1,5 - 2 değerleri arasında olduğu ve otokorelasyon olmadığı söylenebilir.

Tablo 4. Psikolojik Güçlendirmenin Alt Boyutlarının Örgütsel Özdeşleşme ve Birey-Örgüt Uyumu Üzerindeki Etkisini İncelemeye Yönelik Doğrusal Regresyon Analizi ve Bulguları

\begin{tabular}{|c|c|c|c|c|c|c|}
\hline \multicolumn{7}{|c|}{ Bağımsız Değişken: Anlamlılık-Yeterlilik } \\
\hline Bağımlı değişkenler & $\mathbf{R}^{2}$ & $\mathbf{F}$ & $\beta$ & $\mathbf{t}$ & p & DW \\
\hline Örgütsel Özdeşleşme & 25,3 & 71,277 &, 503 & 8,443 &, $000^{*}$ & 1,826 \\
\hline Birey-Örgüt Uyumu & 24,4 & 68,283 & ,494 & 8,2630 &, $000^{*}$ & 1,806 \\
\hline \multicolumn{7}{|c|}{ Bağımsız Değişken: Özerklik } \\
\hline Bağımlı değişkenler & $\mathbf{R}^{2}$ & $\mathbf{F}$ & $\beta$ & $\mathbf{t}$ & p & DW \\
\hline Örgütsel Özdeşleşme & 0,6 & 1,352 & ,080 & 1,163 & ,246 & 1,752 \\
\hline Birey-Örgüt Uyumu & 2,2 & 4,719 & 148 & 2,172 &, $031^{* *}$ & 1,786 \\
\hline \multicolumn{7}{|c|}{ Bağımsız Değişken: $E t k i$} \\
\hline Bağımlı değişkenler & $\mathbf{R}^{2}$ & $\mathbf{F}$ & $\beta$ & $\mathbf{t}$ & p & DW \\
\hline Örgütsel Özdeşleşme & 2,5 & 5,450 & 159 & 2,335 &, $021^{* *}$ & 1,825 \\
\hline Birey-Örgüt Uyumu & 0,2 & ,469 & ,047 & ,685 & ,494 & 1,714 \\
\hline
\end{tabular}

${ }^{*} \mathrm{p}<0.01 ;{ }^{* *} \mathrm{p}<0.05$ düzeyinde anlamlıdır.

Tablo 5'de yer alan doğrusal regresyon bulguları incelendiğinde; örgütsel özdeşleşme değişkeninin \%8,1'inin $\left(\mathrm{R}^{2}=, 081\right)$ birey-örgüt uyumu değişkeni tarafından açıklandığ1 görülmektedir. Bu bulgular 1şığında, birey-örgüt uyumu ile örgütsel özdeşleşme arasında anlamlı ve pozitif bir nedensellik ilişkisinin olduğu görülmektedir. Bu sebeple $\left(\mathrm{H}_{3}\right)$ hipotezi desteklenmektedir $(\beta=, 285, \mathrm{p}<, 001)$. Ayrica, Durbin-Watson istatistiği değerinin 1,5 - 2 değerleri arasında olduğu ve otokorelasyon olmadığ söylenebilir. 
Tablo 5. Birey-Örgüt Uyumu ile Örgütsel Özdeşleşme Arasındaki İlişkiyi İncelemeye Yönelik Doğrusal Regresyon Analizi ve Bulguları

\begin{tabular}{llllllll}
\hline \hline \multicolumn{2}{l}{$\begin{array}{l}\text { Bağımsız Değişken: Birey-Örgüt Uyumu } \\
\text { Bağımlı değişkenler }\end{array}$} & $\mathbf{R}^{2}$ & $\mathbf{F}$ & $\boldsymbol{\beta}$ & $\mathbf{t}$ & $\mathbf{p}$ & $\mathbf{D W}$ \\
\hline \hline Örgütsel Özdeşleşme & 8,1 & 18,626 &, 285 & 4,316 &, $000^{*}$ & 1,786 \\
\hline \hline
\end{tabular}

${ }^{*} \mathrm{p}<0.01$ düzeyinde anlamlıdır.

\subsection{Hiyerarşik Regresyon ve Bulguları}

Çalışmada değişkenler arasındaki aracılık etkisini ölçmek amacıyla ise hiyerarşik regresyon analizinden yararlanılmıştır (Tablo 6 ve 7). Psikolojik güçlendirmenin örgütsel özdeşleşme üzerindeki etkisinde birey-örgüt uyumunun aracılık rolünü açıklamak amacıyla, Baron ve Kenny (1986) tarafından önerilen hiyerarşik regresyon analizi yapılmıştır. Bu yönteme göre, bağımsız değişkenin (psikolojik güçlendirme) bağımlı değişken (örgütsel özdeşleşme) ve aracı değişken (birey-örgüt uyumu) üzerinde bir etkisi olmalıdır. Aracı değişken bağımsız değişkenle birlikte regresyon analizine dahil edildiğinde, bağımsız değişkenin bağımlı değişken üzerindeki regresyon katsayısı düşerken, aracı değişkenin de bağımlı değişken üzerinde anlamlı etkisi sürmelidir (Akkoç vd., 2012:122). Bir değişkenin aracı (mediator) olarak değerlendirilebilmesi için aşağıdaki şartları sağlaması gerekmektedir (Baron ve Kenny, 1986:1173-1182; Turunç ve Çelik, 2010:197);

1. Bağımsız değişkenin (psikolojik güçlendirme/alt boyutları) bağımlı değişken (örgütsel özdeşleşme) üzerinde anlamlı bir etkisinin olması,

2. Bağımsız değişkenin (psikolojik güçlendirme/alt boyutları) aracı değişken (birey-örgüt uyumu) üzerinde anlamlı bir etkisinin olması,

3. Aracı değişken (birey-örgüt uyumu) analize dahil edildiğinde, bağımlı değişken (örgütsel özdeşleşme) ile bağımsız değişken (psikolojik güçlendirme/alt boyutları) arasında daha önce anlamlı olan ilişkinin, anlamlılık seviyesinin tamamen ortadan kalkması ya da önceki seviyeye kıyasla azalması gerekmektedir. Bu etkinin tamamen ortadan kalması güçlü ve tek değişken olduğunu yani tam aracılık (full mediation) durumunu gösterir. Tamamen ortadan kalkmadan azalıyor olması ise başka aracı değişkenlerin de varlığına yani kısmi aracılık (partial mediation) durumuna işaret etmektedir. Ayrıca, aracılık etkisinin (beta değerindeki azalma miktarının) anlamlı olup olmadığı sobel testi ile analiz edilmiştir. 
Tablo 6. Psikolojik Güçlendirmenin Örgütsel Özdeşleşme Üzerindeki Etkisinde Birey-Örgüt Uyumunun Aracılık Rolünü İncelemeye Yönelik Hiyerarşik Regresyon Analizi ve Bulguları

\begin{tabular}{|c|c|c|c|c|c|c|}
\hline \multicolumn{7}{|l|}{ Model 1} \\
\hline Bağımsız Değişken & Bağımlı Değişken & $\mathbf{R}^{2}$ & $\mathbf{F}$ & $\beta$ & $\mathbf{t}$ & $\mathbf{p}$ \\
\hline Psikolojik Güçlendirme & Örgütsel Özdeşleşme & 14,4 & 35,449 & 379 & 5,954 &, $000^{*}$ \\
\hline \multicolumn{7}{|l|}{ Model 2} \\
\hline Bağımsız Değişken & Bağımlı Değişken & $\mathbf{R}^{2}$ & $\mathbf{F}$ & $\beta$ & $\mathbf{t}$ & $\mathbf{p}$ \\
\hline Psikolojik Güçlendirme & Birey-Örgüt Uyumu & 12,7 & 30,598 & 356 & 5,532 &, $000^{*}$ \\
\hline Birey-Örgüt Uyumu & Örgütsel Özdeşleşme & 8,1 & 18,626 & 285 & 4,316 &, $000^{*}$ \\
\hline \multicolumn{7}{|l|}{ Model 3} \\
\hline Bağımsız Değişken & Bağımlı Değişken & $\mathbf{R}^{2}$ & $\mathbf{F}$ & $\beta$ & $\mathbf{t}$ & $\mathbf{p}$ \\
\hline Psikolojik Güçlendirme & \multirow{2}{*}{ Örgütsel Özdeşleşme } & \multirow{2}{*}{17,0} & \multirow{2}{*}{21,437} & ,318 & 4,728 &, $000^{*}$ \\
\hline Birey-Örgüt Uyumu & & & & 172 & 2,550 &, $011^{* *}$ \\
\hline
\end{tabular}

${ }^{*} \mathrm{p}<0.01 ;{ }^{* *} \mathrm{p}<0.05$ düzeyinde anlamlıdır.

Sobel $Z=2,3195, p=0.02$

Tablo 6'da yer alan doğrusal ve hiyerarşik regresyon analizlerine ilişkin Model 1 ve Model 2' de; örgütsel özdeşleşme değişkeninin $\% 14,4^{\prime}$ ünün $\left(\mathrm{R}^{2}=, 144\right)$ ve birey-örgüt uyumu değişkeninin \%12,7'inin $\left(\mathrm{R}^{2}=, 127\right)$ psikolojik güçlendirme değişkeni tarafından açıklandığı ve $\mathrm{p}<0,01$ düzeyinde anlamlı olduğu görülmektedir. Model 2'de, örgütsel özdeşleşme değişkeninin \%8,1'inin birey-örgüt uyumu değişkeni tarafından açıklandığı $\left(R^{2}=, 081\right)$ ve $p<0,01$ düzeyinde anlamlı olduğu söylenebilir. Model 1 ve Model 2 ile elde edilen bulgular 1şı̆̆ında, Model 3'te belirtilen aracılık etkisine bakılabilir. Bu kapsamda Model 3'te; örgütsel özdeşleşme değişkeninin \%17'sinin psikolojik güçlendirme ve birey-örgüt uyumu değişkenleri tarafından açıklandığ $\left(\mathrm{R}^{2}=, 170\right)$ ve $\mathrm{p}<0,01$ düzeyinde anlamlı olduğu söylenebilir. Ayrıca, Model 1 'deki psikolojik güçlendirme değişkeninin regresyon katsayısı olan Beta'nın değeri $(\beta=, 379)$, Model 3'te birey-örgüt uyumu aracı değişkeninin katılması ile $(\beta=, 318)$ azalmıştır, ancak tamamen ortadan kalkmamıştır $(p<0,01)$. Aynı şekilde birey-örgüt uyumu aracı değişkeni de anlamlı $(\mathrm{p}<0,05)$ kalmıştır. Tüm bu bulgular 1şı̆̆ında, "çalışanların psikolojik güçlendirme algılarının örgütsel özdeşleşme üzerindeki etkisinde birey-örgüt uyumunun aracılık rolü vardır" hipotezi $\left(\mathrm{H}_{4}\right)$ "kısmı aracılık etkisi vardı" olarak kabul edilmektedir. Sobel test sonucunun anlamlı olmasi değişkenler arasındaki aracılık etkisinin (beta katsayısındaki azalma) anlamlı olduğunu göstermektedir. 
Tablo 7. Psikolojik Güçlendirmenin Alt Boyutlarının Örgütsel Özdeşleşme Üzerindeki Etkisinde Birey-Örgüt Uyumunun Aracılık Rolünü İncelemeye Yönelik Hiyerarşik Regresyon Analizi ve Bulguları

\begin{tabular}{|c|c|c|c|c|c|c|}
\hline Bağımsız Değişken & Bağımlı Değişken & $\mathbf{R}^{2}$ & F & $\beta$ & $t$ & $\mathbf{p}$ \\
\hline \multicolumn{7}{|l|}{ Model 1} \\
\hline \multirow{2}{*}{ Anlamlılık-Yeterlilik } & Birey-Örgüt Uyumu & 24,4 & 68,283 & ,494 & 8,2630 &, $000^{*}$ \\
\hline & \multirow{4}{*}{$\begin{array}{l}\text { Örgütsel } \\
\text { Özdeşleşme }\end{array}$} & 25,3 & 71,277 & ,503 & 8,443 &, $000^{*}$ \\
\hline Birey-Örgüt Uyumu & & 8,1 & 18,626 & 285 & 4,316 &, $000^{*}$ \\
\hline Anlamlılık-Yeterlilik & & \multirow{2}{*}{25,4} & \multirow{2}{*}{35,799} & ,479 & 6,983 &, $000^{*}$ \\
\hline Birey-Örgüt Uyumu & & & & 048 & ,702 & ,484 \\
\hline \multicolumn{7}{|l|}{ Model 2} \\
\hline \multirow{2}{*}{ Özerklik } & Birey-Örgüt Uyumu & 2,2 & 4,719 & 148 & 2,172 &, $031^{* *}$ \\
\hline & \multirow{2}{*}{$\begin{array}{c}\text { Örgütsel } \\
\text { Özdeşleşme }\end{array}$} & 0,6 & 1,352 & 080 & 1,163 & ,246 \\
\hline Birey-Örgüt Uyumu & & 8,1 & 18,626 & ,285 & 4,316 &, $000^{*}$ \\
\hline \multicolumn{7}{|c|}{$\begin{array}{l}\text { Özerklik ile Örgütsel Özdeşleşme arasındaki nedensellik ilişkisi anlamlı olmadığından } \\
\qquad(\mathrm{p}<0,05) \text { aracılık etkisine bakılmamıştır. }\end{array}$} \\
\hline \multicolumn{7}{|l|}{ Model 3} \\
\hline \multirow{2}{*}{ Etki } & Birey-Örgüt Uyumu & 0,2 & 469 & 047 & 685 & ,494 \\
\hline & \multirow{2}{*}{$\begin{array}{l}\text { Örgütsel } \\
\text { Özdeşleşme }\end{array}$} & 2,5 & 5,450 & 159 & 2,335 &, $021^{* *}$ \\
\hline Birey-Örgüt Uyumu & & 8,1 & 18,626 & 285 & 4,316 &, $000^{*}$ \\
\hline \multicolumn{7}{|c|}{$\begin{array}{c}\text { Etki ile Birey-Örgüt Uyumu arasındaki nedensellik ilişkisi anlamlı olmadığından }(p<0,05) \\
\text { aracılık etkisine bakılmamıştır. }\end{array}$} \\
\hline
\end{tabular}

${ }^{*} \mathrm{p}<0.01 ;{ }^{* *} \mathrm{p}<0.05$ düzeyinde anlamlıdır.

Tablo 7'de yer alan doğrusal ve hiyerarşik regresyon analizlerine ilişkin Model 1 'de; örgütsel özdeşleşme değişkeninin \%25,3'ünün $\left(R^{2}=, 253\right)$ ve birey-örgüt uyumu değişkeninin \%24,4'ünü $\left(R^{2}=, 244\right)$ psikolojik güçlendirmenin alt boyutu olan "anlamlılık-yeterlilik" değişkeni tarafından açılandığı ve $\mathrm{p}<0,01$ düzeyinde anlamlı olduğu görülmektedir. Bu durumda aracılık etkisine bakılabilir. Bu kapsamda, örgütsel özdeşleşme değişkeninin \%25,4'ünün anlamlılık-yeterlilik ve birey-örgüt uyumu değişkenleri tarafından açıklandığ $\left(R^{2}=, 254\right)$ ve $p<0,01$ düzeyinde anlamlı olduğu söylenebilir. Ayrıca, anlamlılık-yeterlilik değişkeninin regresyon katsayısı olan Beta değeri $(\beta=, 503)$, birey-örgüt uyumu aracı değişkeninin katılması ile $(\beta=, 479)$ azalmıştır, ancak tamamen ortadan kalkmamıştır $(\mathrm{p}<0,01)$. Ancak, birey-örgüt uyumu aracı değişkeni anlamlılığını $(\mathrm{p}>0,05)$ kaybetmiştir. Model 1'de yer alan bulgular ışığında, "çalışanların psikolojik güçlendirmenin alt boyutu olan anlamlılık-yeterlilik algılarının örgütsel özdeşleşme üzerindeki etkisinde birey-örgüt uyumunun aracılık rolü vardır" hipotezi $\left(\mathrm{H}_{4 a-b}\right)$ desteklenmemektedir. Model 2 'de yer alan bulgular incelendiğinde; psikolojik güçlendirmenin alt boyutu olan "özerklik" değişkeninin örgütsel özdeşleşme üzerinde herhangi bir nedensellik ilişkisinin olmadığı $(p>0,05)$ 
görülmektedir. Aynı şekilde Model 3'de de psikolojik güçlendirmenin alt boyutu olan "etki" değişkeninin birey-örgüt uyumu aracı değişkeni üzerinde herhangi bir nedensellik ilişkisinin olmadığ1 $(p>0,05)$ görülmektedir. Model 2 ve Model 3 'deki bulgular kapsamında aracılık etkisine bakılmamıştır. Böylece $\left(\mathrm{H}_{4 c}\right.$ ve $\left.\mathrm{H}_{4 d}\right)$ desteklenmemiştir.

\section{Sonuç}

Günümüz bilgi ve teknoloji çağında örgütler amaçlarına ulaşabilmek, rekabet edebilmek ve sürdürülebilirliğini sağlamak için her konuda donanımlı, güçlü ve yaratıcı çalışanlara ihtiyaç duymaktadırlar. Örgütler, bu ihtiyaçlarını gidermek için çalışanlarını eksik oldukları veya geliştirmek istedikleri konularda güçlendirmektedir. Psikolojik güçlendirme algısı yüksek olan çalışan ise örgütü ile uyumu yakalayabilecek ve kendini örgütün bir parçası gibi görüp, örgütü ile özdeşleşebilecektir. Bu durum hem örgüt hem de çalışan için "kazan-kazan" mantı̆̆ çerçevesinde her iki tarafa da yarar sağlayabilecektir.

Araştırmanın bulgularına göre; psikolojik güçlendirme ile örgütsel özdeşleşme ve birey-örgüt uyumu arasında pozitif ve anlamlı bir korelasyonun ve regresyonun olduğu görülmüştür. Çalışanların örgütleri tarafından güçlendirilmesi, onların psikolojik güçlendirme algıladıklarını artırabilmekte, bu da çalışanların örgütlerine olan bağlılıklarını ve özdeşleşmelerini sağlayabilmektedir. Buna ek olarak, örgütleri tarafından güçlendirilmiş çalışanlar amaç, değer, norm ve inançları bakımından örgütü ile uyum içinde olabilmektedir. Psikolojik güçlendirmenin alt boyutlarından anlamlılık-yeterlilik boyutunun örgütsel özdeşleşme ve birey-örgüt uyumu ile özerklik boyutunun birey-örgüt uyumu ile ve etki boyutunun ise örgütsel özdeşleşme ile anlamlı ve pozitif bir ilişkisinin olduğu söylenebilir. Çalışanlar, mevcut değer, inanç, tutum ve tecrübeleri ile işin gereklerinin üstesinden gelmesi ve örgütü ile uyum yakalaması (anlamlılık-yeterlilik) örgütü ile özdeşlemesine ve uyumlu olasına neden olabilmektedir. Ayrıca, çalışanlar kendilerine karar alabilme özgürlügünü (özerklik) sağlayan örgütleri ile uyumlu olmasını ve iş yerindeki stratejik ve yönetsel faaliyetlere etki edebilmesi onların örgütleri ile özdeşleşmelerini sağlayabilmektedir. $\mathrm{Bu}$ bulgular yazında yapılmış diğer araştırmalar ile aynı doğrultuda sonuçlar gösterdiği söylenebilir. Yarmacı (2012), psikolojik güçlendirmenin örgütsel özdeşleşme üzerindeki etkisinin incelendiği çalışmada, psikolojik güçlendirmenin örgütsel özdeşleşmeyi orta düzeyde etkilediği, psikolojik güçlendirmenin anlam ve etki boyutlarının, yeterlilik ve özerklik boyutlarına oranla daha fazla rol oynadığ 1 tespit edilmiştir. Prati ve Zani (2013), psikolojik güçlendirme ve örgütsel özdeşleşme arasındaki ilişkiyi araştırdıklarında çalışmada, psikolojik güçlendirmenin örgütsel özdeşleşmeyi pozitif ve anlamlı olarak etkilediği sonucuna varmışlardır. Polat vd. (2010), personel güçlendirme, örgütsel sinizm ve örgütsel özdeşleşme arasındaki ilişkileri belirlemek amacıyla gerçekleştirdikleri çalışmada, personel güçlendirmenin örgütsel özdeşleşme üzerinde pozitif ve anlamlı bir etkisinin olduğu belirlemişlerdir. Meydan vd. (2010), bireyin güçlendirilmişlik algısının örgütle özdeşleşmesine etkisini belirlemek amacıyla gerçekleştirdikleri çalışmada, personel güçlendirme ve alt boyutlarından anlamlılık ile örgütsel özdeşleşme arasında pozitif ve anlamlı bir ilişki bulmuşlardır. Ertürk (2010) çalışmasında, çalışanların psikolojik güçlendirme 
algılarının artması onların örgütleri ile özdeşleşme düzeylerini arttırdığını belirtmiştir. Aynı şekilde Zhu vd. (2012) araştırmalarında, psikolojik güçlendirmenin örgütsel özdeşleşme üzerinde pozitif bir etkisinin olduğunu saptamışlardır. Akkoç vd., (2013) araştırmalarında, çalışanların psikolojik güçlendirme algıları ile bireyörgüt uyumu arasında anlamlı ve pozitif bir ilişkinin olduğu belirtmektedir.

Psikolojik güçlendirmenin örgütsel özdeşleşme üzerindeki etkisinde birey-örgüt uyumunun kısmı aracılık etkisi olduğu tespit edilmiştir. Örgütler, çalışanlarının özdeşleşme davranışı göstermeleri için onları her konuda güçlendirmesi ve algılarının arttırılmasının yanında, çalışanlar ile değer, inanç, norm ve kültür bağlamında da uyum sağlanması gerekmektedir. Psikolojik güçlendirmenin alt boyutlarının (anlamlılık-yeterlilik, özerklik, etki) örgütsel özdeşleşme üzerindeki etkisinde birey-örgüt uyumunun herhangi bir aracılık etkisinin olmadığı belirtilebilir. Özerklik ile örgütsel özdeşleşme ve etki ile birey-örgüt uyumu arasında nedensellik ilişkisi anlamlı olmadığından aracılık etkisinden bahsetmek mümkün değildir. $\mathrm{Bu}$ kapsamda yazında aracı etki ile ilgili herhangi bir araştırmaya rastlanmadığından kıyaslama yapılmamıştır. Bu bulgular ışığında örgütler, rakipleri ile rekabet edebilmek ve hayatta kalabilmek için çalışanlarını güçlendirebilir ve onların örgütleri ile özdeşleşmesini sağlayabilirler. Psikolojik güçlendirme algıları yüksek olan çalışanların örgütleri ile uyum düzeyleri de yüksek olabileceği, dolayısıyla bu durum kendilerini örgütleri ile özdeşleşmelerini artırabileceği söylenebilir.

\section{Kaynakça}

Akbaş, T. T. (2011). Algılanan Kişi-Örgüt Uyumunun Örgütsel Vatandaşlık Davranışları Üzerindeki Etkisi: Görgül Bir Araştırma. Yönetim Bilimleri Dergisi, 9(1): 56-81.

Akkoç, İ., Çalışkan, A. ve Turunç, Ö. (2012). Örgütlerde Gelişim Kültürü ve Algılanan Örgütsel Desteğin İş Tatmini ve İş Performansına Etkisi: Güvenin Aracılık Rolü. Yönetim ve Ekonomi, 19(1): 105-135.

Akkoç, İ., Çalışkan, A., Özalp, D. ve Uçak, P. (2013). Psikolojik Güçlendirme, Etik İklim ve Dağıtımsal Adaletin Kişi Örgüt Uyumuna Etkisinde Öz Yeterlilĭgin Rolü. 21. Ulusal Yönetim ve Organizasyon Kongresi Bildiriler Kitabı, Kütahya.

Altındiş, S. ve Özutku, H. (2011). Psikolojik Güçlendirme ve Güçlendirmeyi Etkileyen Faktörler: Türkiye'deki Devlet Hastanelerinde Bir Araştırma. Sosyal Bilimler Dergisi, XIII(1): 162-191.

Altunışık, R., Coşkun, R., Bayraktaroğlu, S., Yıldırım, E. (2004). Sosyal Bilimlerde Araştırma Yöntemleri: SPSS Uygulamal. Sakarya Kitabevi, İstanbul.

Autry, C. W. ve Daugherty, P. J. (2003). Warehouse Operations Employees: Linking Person-Organization Fit, Job Satisfaction, and Coping Responses. Journal of Business Logistics, 24(1): 171-197.

Bandura, A. (1995). Self-Efficacy in Changing Societies. Edit. Albert Bandura, Cambridge University Pres, Cambridge. 
Baron, M. R. ve Kenny, A. D. (1986). The Moderator-Mediator Variable Distinction in Social Pyschological Research. Conceptual, Strategic and Statistical Considerations. Journal of Personality and Psychology, 51(6): 1173-1182.

Bretz, D. R. ve Judge, A. T. (1994). Person-Organization Fit and the Theory of Work Adjustment: Implications for Satisfaction, Tenure, and Career Success. Journal of Vocational Behavior, 44(1): 32-54.

Bulut, E. Y. ve Torun, A. (2007). Birey-İş Uyumu ve Sosyal Desteğin İş Stresi Üzerine Etkileri: Çă̆r Merkezlerinde Bir Çalışma. 15. Yönetim ve Organizasyon Kongresi, Sakarya.

Cable, D. M., ve Judge, T. A. (1994). Pay Preferences and Job Search Decisions: A Person Organization Fit Perspective. Personnel Psychology, 47(2): 317-348.

Can, H., Azizoğlu, A. Ö. ve Aydın, M. E. (2015). Örgütsel Davranış. 2. Baskı, Ankara: Siyasal Kitabevi.

Carmeli, A., Gilat, G. ve Waldman, D. A. (2007). The Role of Perceived Organizational Performance in Organizational Identification, Adjustment and Job Performance. Journal of Management Studies, 44(6): 972-992.

Chatman, A. J. (1989). Improving Interactional Organizational Research: A Model of Person-Organization Fit. Academy of Management Review, 14(3), 333-349.

Conger, J. A. ve Kanungo, N. R. (1988). “The Empowerment Process: Integrating Theory and Practice". Academy of Management Review, 13(3): 471-482.

Çalışkan, C. S. (2011). Çalışanların Psikolojik Güçlendirme Algıları Üzerinde İş Yeri Arkadaşlıkları ve Örgütsel İletişimin Etkisi. Ç.Ü. Sosyal Bilimler Enstitüsü Dergisi, 20(3): 77-92.

Çetinkaya, M. ve Çimenci, S. (2014). Örgütsel Adalet Algısının Örgütsel Vatandaşlık Davranışı Üzerindeki Etkisi ve Örgütsel Özdeşleşmenin Aracılık Rolü: Yapısal Eşitlik Modeli Çalışması. Yönetim Bilimleri Dergisi, 12(23): 237-278.

Dick, R. (2001). Identification in Organizational Contexts: Linking Theory and Research From Social and Organizational Psychology. International Journal of Management Reviews, 3: 265-283.

Ertürk, A. (2010). Exploring Predictors of Organizational Identification: Moderating Role of Trust on The Associations between Empowerment, Organizational Support, and Identification. European Journal of Work and Organizational Psychology, 19(4): 409-441.

Hales, C. ve Klidas, A. (1998). Empowerment in Five-Star Hotels: Choice, Voice or Rhetoric? Contemporary Hopitality Management, 10(3): 88-95.

Hall, M. (2008). The Effect of Comprehensive Performance Measurement Systems on Role Clarity, Psychological Empowerment and Managerial Performance. Accounting, Organizations and Society, 33: 141-163.

Hemedoğlu, E., Koçak, M., Özkan, A. ve Berberoğlugil, M. B. (2012). Psikolojik Güçlendirmenin Finansal Olmayan Performans Üzerindeki Etkileri. Eskişehir Osmangazi Üniversitesi Sosyal Bilimler Dergisi, 13(2): 87-105.

Hoffman, B. J. ve Woehr, D. J. (2006). A Quantitative review of the Relationship Between Person-Organization Fit and Behavioral Outcomes. Journal of Vocational Behavior, 68: 389-399. 
Honold L. (1997). A Review of the Literature on Employee Empowerment. Empowerment in Organizations, 5(4): 202-212.

Hu, S. L. Y. ve Leung, L. (2003). Effects of Expectancy-Value, Attitudes, and Use of the Internet on Psychological Empowerment Experienced by Chinese Women at the Workplace. Telematics and Informatics, 20(4): 365-382.

Jha, S. (2014). Transformational Leadership And Psychological Empowerment Determinants of Organizational Citizenship Behavior. South Asian Journal of Global Business Research, 3(1): 18-35.

Kanbur, E. (2016). Psikolojik Güçlendirme, İş Performansı ve İşten Ayrılma Niyeti Arasındaki İlişkilerin Değerlendirilmesi. 3rd International Congress on Social Sciences, China to Ardiatic, Antalya.

Kanbur, E., Canbek, M. ve Özyer, K. (2016). Örgütlerde Rol Belirsizliği ve Rol Çatışmasının Çalışanların Öz-Yeterlilik Algıları Üzerindeki Etkisi. Örgütsel Davranış Araştırmaları Dergisi, 1(1), 16-34.

Karakaş, A. ve Serçek, S. (2014). Psikolojik Güçlendirme Algısının Örgütsel Bağlılığa Etkisi: Otel Çalışanları Üzerine Bir Araştırma. Seyahat ve Otel İşletmeciliği Dergisi, 11 (2): 90-107.

Kim, T. Y., Cable, M. D. ve Kim, S. P. (2005). Socialization Tactics, Employee Proactivity, and Person-Organization Fit. Journal of Applied Psychology, 90(2): 232241.

Kristof, A. L. (1996). "Person-organization Fit: an Integrative Review of Its Conceptualizations, Measurement, and Implications". Personnel Psychology, 49:149.

Knippenberg, D. ve Schie, E. C. N. (2000). Foci and Corretes of Organizational Identification. Journal of Occupational and Organizational Psychology, 73: 137-147.

Koçel, T. (2001). İşletme Yöneticiliği. İstanbul: Beta Kitap.

Laschinger, H. K. S., Finegan, J. E., Shamian, J. ve Wilk, P. (2004). A Longitudinal Analysis of the Impact of Workplace Empowerment on Work Satisfaction. Journal of Organizational Behavior, 25(4): 527-545.

Liu, B., Liu, J. ve Hu, J. (2010). Person-Organization Fit, Job Satisfaction, and Turnover Intention: An Empirical Study in the Chinese Public Sector. Social Behavior and Personality: an international journal, 38(5): 615-625.

Mael, F. ve Ashforth, E. B. (1992). Alumni and Their Alma Mater: A Partial Test of The Reformulated Model of Organizational Identification. Journal of Organizational Behavior, 13(2): 103-123.

Meydan, C.H., Polat, M. ve Burmanoğlu, S. (2010). Bireyin Güçlendirilmişlik Algısının Örgütle Özdeşleşmesine Etkisi: Kamuda Bir Araştırma. KHO Bilim Dergisi, 20(1): 37-60.

Meyer, P. J., Hecht, D. T., Gill, H. ve Toplonytsky, L. (2010). Person-Organization (Culture) Fit and Employee Commitment Under Conditions of Organizational Change: A Longitudinal Study. Journal of Vocational Behavior, 76: 458-473.

Pekdemir, I., Koçoğlu, M. ve Gürkan, Ç. G. (2013). Birey-Örgüt Uyumunun Açıç̧a Konuşma Davranışı Üzerindeki Etkisinde Algılanan Yönetici Desteğinin Aracılık 
Rolü: MBA Öğrencilerine Yönelik Bir Araştırma. İ.Ü. İşletme Fakültesi İşletme İktisadi Enstitüsü Yönetim Dergisi, 24(75): 83-104.

Pelit, E. ve Öztürk, Y. (2011). Otel İşletmeleri İşgörenlerinin Davranışsal ve Psikolojik Güçlendirme Algılamalarındaki Farklılıklar. Ekonomik ve Sosyal Araştırmalar Dergisi, 7(1):1-28.

Polat, M., Meydan, H. ve Tokmak, G. (2010). Personel Güçlendirme-Örgütsel Sinizm İlişkisinde Örgütsel Özdeşleşmenin Aracılık Etkisi. 9. Ulusal İşletmecilik Kongresi Bildiri Kitab1, Zonguldak.

Polatçı, S. ve Cindiloğlu, M. (2013). Kişi-Örgüt Uyumunun Örgütsel Vatandaşlık Davranışına Etkisi: Duygusal Bağlılığın Aracılık Rolü. Süleyman Demirel Üniversitesi İktisadi ve İdari Bilimler Fakültesi Dergisi, 18(3): 299-318.

Polatçı, S., Özçalık, F. ve Cindiloğlu, M. (2014). Üretkenlik Karşıtı İş Davranışı ve Örgütsel Vatandaşlık Davranışı Üzerinde Kişi-Örgüt Uyumunun Etkileri. İktisadi ve İdari Bilimler Fakültesi Dergisi, 7(3): 1-12.

Prati, G. ve Zani, B. (2013). The Relationship Between Psychological Empowerment and Organizational Identification. Journal of Community Psychology, 41(7): 851-866.

Riketta, M. (2005). Organizational identification: A meta-Analysis. Journal of Vocational Behavior, 66: 358-384.

Sekiguchi, T. (2004). Person- Organization Fit and Person Job Fit in Employee Selection: A Review of the Literature. Osaka Keidai Ronshu, 54(6): 179-196.

Sezgin, F. (2006). İlköğretim Okulu Öğretmenlerinin Birey-Örgüt Değer Uyumuna İlişkin Algıları. Kuram ve Uygulamada Ĕ̆itim Yönetimi, 48: 557-583.

Silverthorne, C. (2004). The Impact of Organizational Culture and PersonOrganization Fit on Organizational Commitment and Job Satisfaction in Taiwan. The Leadership \& Organization Development Journal, 25(7): 592-599.

Singh, M., Gupta, A. ve Handa, P. (2015). Domain Satisfaction Predictors of Psychological Empowerment and Determinants. Journal of Strategic Human Resource Management, 4(2): 56-64.

Sökmen, A., Ekmekçioğlu, E. B. ve Çelik, K. (2015). Algılanan Örgütsel Destek, Örgütsel Özdeşleşme ve Yönetici Etik Davranışı İlişkisi: Araştırma Görevlilerine Yönelik Araştırma. İşletme Araştırmaları Dergisi, 7(1):125-144.

Spreitzer, G. M. (1995). Psychological Empowerment in the Workplace: Dimensions, Measurement, and Validation. The Academy of Management Journal, 38(5): 14421465.

Spreitzer, G. M. (1996). Social Structural Characteristics of Psychological Empowerment. Academy of Management Journal, 39(2): 483-504.

Spreitzer, G. M., Kizilos, M. A. ve Nason, S. W. (1997). A Dimensional Analysis of the Relationship between Psychological Empowerment and Effectiveness, Satisfaction, and Strain. Journal of Management, 23(5): 679-704.

Sürgevil, O., Tolay, E. ve Topoyan, M. (2013). Yapısal Güçlendirme ve Psikolojik Güçlendirme Ölçeklerinin Geçerlilik ve Güvenilirlik Analizleri. Journal of Yaşar University, 8(31): 5371-5391.

Tak B. ve Aydemir, B. A. (2004). Örgütsel Özdeşleşme Üzerine İki Görgül Çalışma. 12.Ulusal Yönetim ve Organizasyon Kongresi Bildiri Kitabı, Bursa. 
Tak, B. ve Çifçioğlu, A. (2009). Algılanan Örgütsel Prestij İle Örgütsel Bağlılık Ve Örgütsel Özdeşleşme Arasındaki İlişkilerin İncelenmesine Yönelik Bir Araştırma. Akdeniz İ.İ.B.F. Dergisi, 18: 100-116.

Taştan, Ş. (2012). Bir Pozitif Psikoloji Kavramı Olarak Örgütle Özdeşleşmenin Psikolojik Güçlendirme Algısı ve Gönüllü Performans Davranışı Arasındaki İlişkide Ara Değişken Rolünün Değerlendirilmesi: Gıda Sektöründe Yapılan Bir Araştırma. Organizasyon ve Yönetim Bilimleri Dergisi, 4(1): 227-238.

Tokgöz, E. ve Seymen, A. O. (2013). Örgütsel Güven, Örgütsel Özdeşleşme Ve Örgütsel Vatandaşlık Davranışı Arasındaki İlişki: Bir Devlet Hastanesinde Araştırma. Öneri, 10(39), 61-76.

Toplu, D. ve Akça, M. (2013). Öğrenen Organizasyonun Psikolojik Güçlendirme Üzerindeki Etkisi: Kamu Sektöründe Bir Araştırma. Istanbul Ticaret Üniversitesi Sosyal Bilimleri Dergisi, 12(23): 221-235.

Turunç, Ö. ve Çelik, M. (2010). Algılanan Örgütsel Desteğin Çalışanların İş-Aile, Aileİş Çatışması, Örgütsel Özdeşleşme ve İşten Ayrılma Niyetine Etkisi: Savunma Sektöründe Bir Araştırma. A.Ü. SBE Dergisi, 14(1): 209-232.

Verquer, M. L., Beehr, T. A. ve Wagner, S. H. (2003). A Meta- Analysis of Relations Between Person-Organization Fit and Work Attitudes. Journal of Vocational Behavior, 63(3): 473-489.

Whitakera, G. B. ve Westerman, W. J. (2014). Linking Spirituality And Values To Personal Initiative Through Psychological Empowerment. Journal of Management, Spirituality \& Religion, 11(3): 269-291.

Yarmac1, A. (2012). Psikolojik Güçlendirmenin Örgütsel Özdeşleşmeye Etkisi: Otel İşletmelerinde Bir Araştırma. Yüksek Lisans Tezi, Afyon Kocatepe Üniversitesi, SBE, Afyon.

Yücel, İ. ve Demirel, Y. (2012). Psikolojik Güçlendirmenin Örgütsel Vatandaşlık Davranışına Etkisi Üzerine Bir Araştırma. Kocaeli Üniversitesi Sosyal Bilimler Enstitüsü Dergisi, 23: 19-48.

Yürür, Ş. ve Demir, K. (2011). Örgütsel Adalet ve Psikolojik Güçlendirme: Karşılıklı Etkileri Üzerine Bir Araştırma. Süleyman Demirel Üniversitesi İktisadi ve İdari Bilimler Fakültesi Dergisi, 16(3): 311-335.

Zhao, H. (2009). TheEffectsofPersonal-Organization Fit and Organizational Citizenship Behavior on Contextual Performance: AnEmpirical Research. ChineseJournal of Management, 6(3): 342-347.

Zhu, W., Sosik, J. J., Riggio, E. R. ve Yang, B. (2012). Relationships between Transformational and Active Transactional Leadership and Followers' Organizational Identification: The Role of Psychological Empowerment. Leadership and Organizational Identification, 13(3): 186-212.

Zimmerman, A. M. (1995). Psychological Empowerment: Issues and Illustrations. American Journal of Community Psychology, 23(5): 581-599. 